\title{
Breast cancer brain metastases: evidence for neuronal-like adaptation in a 'breast-to-brain' transition?
}

Amanda ED Van Swearingen ${ }^{1}$, Marni B Siegel ${ }^{1,2}$ and Carey K Anders ${ }^{1,3^{*}}$

\begin{abstract}
Brain metastases remain a significant challenge in the treatment of breast cancer patients due to the unique environment posed by the central nervous system. A better understanding of the biology of breast cancer cells that have metastasized to the brain is required to develop improved therapies. A recent Proceedings of the National Academy of Sciences article demonstrates that breast cancer cells in the brain microenvironment express $\gamma$-aminobutyric acid (GABA)-related genes, enabling them to utilize GABA as an oncometabolite, thus gaining a proliferative advantage. In this viewpoint, we highlight these findings and their potential impact on the treatment of breast cancer brain metastases.
\end{abstract}

\section{Breast cancer brain metastases represent a clinically unmet need and are poorly understood} Breast cancer brain metastases (BCBMs) are an increasingly common occurrence and portend a poor prognosis [1]. Treatment of BCBMs represents an unmet medical need as there are currently no approved therapies aside from surgical resection and cranial radiation [2]. Limited systemic treatment options for BCBMs are due, in part, to the unique challenges posed by the neural environment. Protection afforded by the bloodbrain barrier produces an immune-privileged sanctuary and prevents many systemic therapies from penetrating the brain, affording cancer cells unique opportunities to flourish within the neural environment. The added complication of drug delivery to BCBMs coupled with our

\footnotetext{
* Correspondence: carey_anders@med.unc.edu

'Lineberger Comprehensive Cancer Center, University of North Carolina at Chapel Hill, 450 West Drive, Campus Box \#7295, Chapel Hill, NC 27599, USA ${ }^{3}$ Department of Medicine, Division of Hematology/Oncology, University of North Carolina at Chapel Hill, 170 Manning Drive, POB Room 3119, Campus Box \#7305, Chapel Hill, NC 27599, USA

Full list of author information is available at the end of the article
}

poor understanding of the factors unique to BCBM growth, metabolism, and stromal interactions continues to hinder the development of effective therapeutic strategies.

Two major questions regarding BCBMs are (1) what factors optimize BCBM cells to seed and survive in the brain microenvironment, and (2) whether the factors are present in the primary breast cancer cells or are acquired during metastasis. Among the breast cancer subtypes, HER2-enriched (HER2+) and triple-negative primary tumors show higher rates of brain relapse relative to hormone receptor-positive tumors [3,4], suggesting that some innate feature(s) of primary tumor cells may dictate the development of brain metastases. Recent literature suggests that, prior to reaching the brain, some metastatic primary breast cancer cells already express proteins that are essential for the establishment of brain metastases, including serpins [5], matrix metalloproteases [6,7], and $\alpha B$-crystallin [8]. Once in the brain, recent studies have shown BCBM cells transform the surrounding glia and neurons to create a more permissive microenvironment [9-11]. Of note, tumor-activated astrocytes have been shown to play a chemo-protective role for brain metastases [9] and enhance cancer cell proliferation and survival $[6,12]$. Targeting reactive astrocytes in the tumor microenvironment yields therapeutic benefit in vivo by decreasing cancer cell seeding growth in the brain $[13,14]$. Thus, current evidence suggests that BCBMs are the result of both primed breast cancer cells as well as adaptation to and alteration of the braintumor microenvironment. Better understanding of the brain microenvironment and its interactions with breast cancer cells are critical for the development of improved treatments for BCBMs. 


\section{New research provides evidence for breast cancer metabolic adaptation to the unique brain microenvironment}

A recent elegant study by Neman and colleagues [15] investigated whether human BCBMs develop from primed cells in the primary tumor, or if surviving metastatic cells adapt to the brain's unique microenvironment. The authors compare triple-negative and HER2+ primary breast tumors, brain metastases, and representative human-derived cell lines. Relative to both primary tumors and cell lines, the brain metastases exhibit increased expression of several components related to signaling of the inhibitory neurotransmitter $\gamma$-aminobutyric acid (GABA), including $\mathrm{GABA}_{\mathrm{A}}$ receptors, GABA transporters (vesicular GABA transporter, GABA transporter 1-3, GABA-betaine transporter, and glutamate decarboxylase), and GABA transaminase. The study demonstrates that upregulation of GABA-related proteins enables increased transport and metabolism of GABA in BCBMs cells, thereby increasing cell proliferation. The BCBMs cells also acquire features of GABAergic interneurons, expressing interneuron-specific markers like parvalbumin and reelin, characteristics not seen in the primary tumors.

\section{Future treatments should target the permissive brain microenvironment and the resulting adaptations in addition to breast cancer cells themselves}

This work represents one of the few studies that directly compares human primary breast tumors with brain metastases (rather than assessing brain metastases alone and/or breast cancer cell lines in vitro or in mouse models) to identify novel factors involved in BCBM biology. These results also add to a growing body of evidence showing a 'breast-to-brain' transition with cancer cells adapting to the unique brain microenvironment and acquiring neuronal characteristics that are not seen at either the primary and/or other non-brain metastatic sites [16]. The possibility remains, however, that a small population of 'seed' cells in primary tumors are primed for brain metastases with additional adaptations that occur in the brain microenvironment 'soil' $[17,18]$.

The acquisition of a novel, neuronal-like GABA shunt metabolism by the BCBM cells is one of the most groundbreaking findings of Neman and colleagues' article. Cancer cells can exhibit a glycolytic, Warburg-like metabolism instead of oxidative phosphorylation as seen in normal tissues [19]; the GABA shunt in BCBMs reflects yet another metabolic and proliferative advantage utilized by breast cancer cells within the neural environment by providing additional energy through generation of nicotinamide adenine dinucleotide. This acquired metabolism may provide a unique target for brain metastases using therapies that inhibit GABA metabolism.
Notably, several inhibitors of GABA are approved in the clinical setting for treatment of epilepsy [20]; however, careful research is required to determine whether selectively targeting this oncometabolite in the setting of $\mathrm{BCBM}$ will be safe and effective. Additionally, in vivo modeling of GABA metabolism in BCBMs is needed to further establish this adaptive response in the context of a full organism. Ultimately, the work presented by Neman and colleagues places us one step closer to successful therapeutic strategies targeting not only breast cancer cells themselves, but also the supporting brain microenvironment, with the goal of improving survival for patients with BCBM.

\section{Abbreviations}

BCBM: Breast cancer brain metastasis; GABA: $\gamma$-aminobutyric acid.

\section{Competing interests}

The authors declare that they have no competing interests.

Authors' contributions

All authors contributed to the writing and editing of this manuscript.

\section{Acknowledgements}

The authors thank our funding sources, including the NCI/NIH (K23157728 to CKA), the Damon Runyon Cancer Research Foundation (Clinical Investigator award (I-64-12 to CKA), and the NCI/NIH Cancer Cell Biology Training Grant (2-T32-CA071341-16 to MBS). These supporters have not contributed to the writing or submission of this manuscript.

Author details

${ }^{1}$ Lineberger Comprehensive Cancer Center, University of North Carolina at Chapel Hill, 450 West Drive, Campus Box \#7295, Chapel Hill, NC 27599, USA.

${ }^{2}$ Department of Genetics, University of North Carolina at Chapel Hill, 120 Mason Farm Road, Campus Box \#7264, Chapel Hill, NC 27599, USA.

${ }^{3}$ Department of Medicine, Division of Hematology/Oncology, University of North Carolina at Chapel Hill, 170 Manning Drive, POB Room 3119, Campus Box \#7305, Chapel Hill, NC 27599, USA.

Published: 06 May 2014

\section{References}

1. Niwinska A, Murawska M, Pogoda K: Breast cancer brain metastases: differences in survival depending on biological subtype, RPA RTOG prognostic class and systemic treatment after whole-brain radiotherapy (WBRT). Ann Oncol 2010, 21:942-948.

2. Ewend MG, Morris DE, Carey LA, Ladha AM, Brem S: Guidelines for the initial management of metastatic brain tumors: role of surgery, radiosurgery, and radiation therapy. J Natl Compr Canc Netw 2008, 6:505-513. quiz 514.

3. Harrell JC, Prat A, Parker JS, Fan C, He X, Carey L, Anders C, Ewend M, Perou CM: Genomic analysis identifies unique signatures predictive of brain, lung, and liver relapse. Breast Cancer Res Treat 2012, 132:523-535.

4. Smid M, Wang Y, Zhang Y, Sieuwerts AM, Yu J, Klijn JG, Foekens JA, Martens JW: Subtypes of breast cancer show preferential site of relapse. Cancer Res 2008, 68:3108-3114.

5. Valiente M, Obenauf AC, Jin X, Chen Q, Zhang XH, Lee DJ, Chaft JE, Kris MG, Huse JT, Brogi E, Massagué J: Serpins promote cancer cell survival and vascular co-option in brain metastasis. Cell 2014, 156:1002-1016.

6. Wang L, Cossette SM, Rarick KR, Gershan J, Dwinell MB, Harder DR, Ramchandran R: Astrocytes directly influence tumor cell invasion and metastasis in vivo. PLoS One 2013, 8:e80933.

7. Romagnoli M, Mineva ND, Polmear M, Conrad C, Srinivasan S, Loussouarn D, Barillé-Nion S, Georgakoudi I, Dagg A, McDermott EW, Duffy MJ, McGowan PM, Schlomann U, Parsons M, Bartsch JW, Sonenshein GE: ADAM8 
expression in invasive breast cancer promotes tumor dissemination and metastasis. EMBO Mol Med 2014, 6:278-294.

8. Malin D, Strekalova E, Petrovic V, Deal AM, Al Ahmad A, Adamo B, Miller CR, Ugolkov A, Livasy C, Fritchie K, Hamilton E, Blackwell K, Geradts J, Ewend M, Carey L, Shusta EV, Anders CK, Cryns VL: AlphaB-Crystallin: a novel regulator of breast cancer metastasis to the brain. Clin Cancer Res 2014, 20:56-67.

9. Kim SJ, Kim JS, Park ES, Lee JS, Lin Q, Langley RR, Maya M, He J, Kim SW, Weihua Z, Balasubramanian K, Fan D, Mills GB, Hung MC, Fidler IJ: Astrocytes upregulate survival genes in tumor cells and induce protection from chemotherapy. Neoplasia 2011, 13:286-298.

10. Xing F, Kobayashi A, Okuda H, Watabe M, Pai SK, Pandey PR, Hirota S, Wilber A, Mo YY, Moore BE, Liu W, Fukuda K, liizumi M, Sharma S, Liu Y, Wu K, Peralta E, Watabe K: Reactive astrocytes promote the metastatic growth of breast cancer stem-like cells by activating Notch signalling in brain. EMBO Mol Med 2013, 5:384-396.

11. Neman J, Choy C, Kowolik CM, Anderson A, Duenas VJ, Waliany S, Chen BT, Chen MY, Jandial R: Co-evolution of breast-to-brain metastasis and neural progenitor cells. Clin Exp Metastasis 2013, 30:753-768.

12. Fitzgerald DP, Palmieri D, Hua E, Hargrave E, Herring JM, Qian Y, Vega-Valle E, Weil RJ, Stark AM, Vortmeyer AO, Steeg PS: Reactive glia are recruited by highly proliferative brain metastases of breast cancer and promote tumor cell colonization. Clin Exp Metastasis 2008, 25:799-810.

13. Gril B, Palmieri D, Qian Y, Anwar T, Liewehr DJ, Steinberg SM, Andreu Z, Masana D, Fernández P, Steeg PS, Vidal-Vanaclocha F: Pazopanib inhibits the activation of PDGFRbeta-expressing astrocytes in the brain metastatic microenvironment of breast cancer cells. Am J Pathol 2013, 182:2368-2379.

14. Gril B, Palmieri D, Qian Y, Smart D, lleva L, Liewehr DJ, Steinberg SM, Steeg PS: Pazopanib reveals a role for tumor cell B-Raf in the prevention of HER2+ breast cancer brain metastasis. Clin Cancer Res 2011, 17:142-153.

15. Neman J, Termini J, Wilczynski S, Vaidehi N, Choy C, Kowolik CM, Li H, Hambrecht AC, Roberts E, Jandial R: Human breast cancer metastases to the brain display GABAergic properties in the neural niche. Proc Natl Acad Sci U S A 2014, 111:984-989.

16. Park ES, Kim SJ, Kim SW, Yoon SL, Leem SH, Kim SB, Kim SM, Park YY, Cheong JH, Woo HG, Mills GB, Fidler IJ, Lee JS: Cross-species hybridization of microarrays for studying tumor transcriptome of brain metastasis. Proc Natl Acad Sci U S A 2011, 108:17456-17461.

17. Paget $\mathrm{S}$ : The distribution of secondary growths in cancer of the breast. 1889. Cancer Metastasis Rev 1989, 8:98-101.

18. Fidler IJ: The pathogenesis of cancer metastasis: the 'seed and soil' hypothesis revisited. Nat Rev Cancer 2003, 3:453-458.

19. Warburg O: On the origin of cancer cells. Science 1956, 123:309-314.

20. Madsen KK, Larsson OM, Schousboe A: Regulation of excitation by GABA neurotransmission: focus on metabolism and transport. Results Probl Cell Differ 2008, 44:201-221.

10.1186/bcr3651

Cite this article as: Van Swearingen et al:: Breast cancer brain metastases: evidence for neuronal-like adaptation in a 'breast-to-brain' transition? Breast Cancer Research 2014, 16:304 